2018 Global Marketing Conference at Tokyo Proceedings: 707 (July 2018) https://doi.org/10.15444/GMC2018.07.01.03

\title{
THE ROLE OF DIGITAL PLATFORMS IN THE GLOBAL BUSINESS ENVIRONMENT: THE CASE OF CHINA
}

\author{
Francesca Checchinato, Ca' Foscari University of Venice, Italy ${ }^{1}$ \\ Lala $\mathrm{Hu}, \mathrm{Ca}$ ' Foscari University of Venice, Italy ${ }^{2}$
}

\begin{abstract}
Internet represents an increasingly relevant marketing channel for reaching foreign countries (Sinkovics, Sinkovics, \& Jean, 2013). The aim of this paper is to understand how Western firms can exploit digital platforms to enter and sell their products in the contradictory market of China: more advanced than the Western one but also with many restrictions. Drawing from a literature about Internet as communications (Bilby, Reid, \& Brennan, 2016) and sales channel (Bai, McColl, \& Moore, 2017; Deng \& Wang, 2016; Petersen, Welch, \& Liesch, 2002), we develop three propositions to be tested in China. We carry out a qualitative research based on interviews with seven key informants operating in the Chinese market. Findings discuss the peculiarities of the Chinese digital environment. We confirm that dealing with Internet in China is different from other countries, therefore even if companies already have competences related to web marketing, they need to (re)learn how to use it and adapt their marketing strategies. Moreover, despite the growing role of the Internet as retailing channel in the Chinese market, we find that digital platforms do not substitute local distributors because of their primary in guanxi established. Internet has not substituted existing channel intermediaries but it has been rather added to them in a omnichannel strategy
\end{abstract}

Keywords: China, digital marketing, e-commerce, internationalization

\section{References}

Bai, H., McColl, J., \& Moore, C. (2017). Luxury retailers' entry and expansion strategies in China. International Journal of Retail \& Distribution Management, 45(11), 1181-1199.

Bilby, J., Reid, M., \& Brennan, L. (2016). The future of advertising in China: Practitioner insights into the evolution of Chinese advertising creativity. Journal of Advertising Research, 56(3), 245-258.

Chu, S.-C., \& Sung, Y. (2011). Brand personality dimensions in China. Journal of Marketing Communications, 17(3), 163-181.

Deng, Z., \& Wang, Z. (2016). Early-mover advantages at cross-border business-tobusiness e-commerce portals. Journal of Business Research, 69(12), 6002-6011.

Petersen, B., Welch, L. S., \& Liesch, P. W. (2002). The Internet and foreign market expansion by firms. MIR: Management International Review, 42(2), 207-221.

Sinkovics, N., Sinkovics, R. R., \& Jean, R.-J. "Bryan" (2013). The internet as an alternative path to internationalization? International Marketing Review, 30(2), $130-155$.

\footnotetext{
${ }^{1}$ f.checchinato@unive.it

2 lala.hu@unive.it
} 